\title{
Improved Photovoltaic Panel Performance Using a Cylindrical Pin Fins as a Heat Sink
}

\section{Assist Proof, Dr Ibtisam A. Hasan}

Electro mechanical Engineering

Depart.,

University of Technology

Baghdad, Iraq

Email:

dr_ibtisam_ahmed@yahoo.co

m

\section{Assist Proof, Dr Iman S. \\ kareem}

Electro mechanical Engineering

Depart.

University of Technology

Baghdad, Iraq

Email:

dr_esk_71@yahoo.com

\author{
Duha Adil Attar \\ Student master in Electro \\ Mechanical Engineering \\ Department, University of \\ Technology \\ Baghdad., Iraq \\ Email: \\ engduha_1990@yahoo.com
}

\begin{abstract}
:
In this work, the photovoltaic panel performance has been investigated theoretically and experimentally where using an array of pin fins as a cooling system. Trying to satisfy the ideal operation conditions of the solar panel, heat sink was fixated on the back of the PV panel to use as a passive technique. An Analytical thermal model based on the steady state and one dimension analysis condition was built to transfer the excess heat from PV panel with the heat sink existing to predict the operation temperature of PV panel. Theoretical results were compared with experimental results of solar panels cooled by heat sink, in order to validate the suggested thermal model. Also, the effect of the solar cells temperature on the panel performance has been studied experimentally. The results displays that using pin fins array as a cooling technique led to drop in the average panel's temperature nearly $5.9^{\circ} \mathrm{C}$ and an enhancement of the average output power nearly $13.5 \%$.
\end{abstract}

Keywords: heat sink, passive cooling technique, pin fins, solar panel

\begin{tabular}{|c|c|c|c|c|c|}
\hline Symbol & Meaning & Unit & Symbol & Meaning & Unit \\
\hline $\mathrm{A}_{\mathrm{B}}$ & The base area of heat sink & $\mathrm{m}^{2}$ & $\mathrm{~A}_{\mathrm{cf}}$ & $\begin{array}{l}\text { Fin cross section area } \\
\left(\pi D_{f}^{2} / 4\right)\end{array}$ & $\mathrm{m}^{2}$ \\
\hline $\mathrm{A}_{\text {chs }}$ & channel area of heat sink & $\mathrm{m}^{2}$ & $A_{\mathrm{Fb}}$ & $\begin{array}{l}\text { Free surface area of heat } \\
\text { sink base }\end{array}$ & $\mathrm{m}^{2}$ \\
\hline$A_{\text {fin }}$ & $\begin{array}{l}\text { area of outer surfaces of the } \\
\text { fin }=\pi D_{f} L_{\text {fin }}\end{array}$ & $\mathrm{m}^{2}$ & $A_{\text {total }}$ & $\begin{array}{l}\text { Outer surface area of heat } \\
\text { sink }\end{array}$ & $\mathrm{m}^{2}$ \\
\hline $\mathrm{bc}$ & Backing factor & & $\mathrm{Cp}$ & heat capacity & $\mathrm{J} / \mathrm{kg} .{ }^{\circ} \mathrm{C}$ \\
\hline ds & $\begin{array}{l}\text { The distance between center } \\
\text { to center of fins }\end{array}$ & $\mathrm{m}$ & $\mathrm{E}_{\mathrm{p}}$ & $\begin{array}{l}\text { The output electrical } \\
\text { energy }\end{array}$ & $\mathrm{W}$ \\
\hline Effect $_{H S}$ & $\begin{array}{l}\text { The overall finned surface } \\
\text { effectiveness of heat sink }\end{array}$ & & $\mathrm{F}_{\mathrm{g}}$ & $\begin{array}{l}\text { The shape factor of glass } \\
\text { layer with ground }\end{array}$ & \\
\hline Symbol & Meaning & Unit & Symbol & Meaning & Unit \\
\hline $\mathrm{F}_{\text {sky }}$ & $\begin{array}{l}\text { The shape factor of glass } \\
\text { layer with sky }\end{array}$ & & $\mathrm{h}$ & Convection coefficient & $\mathrm{W} / \mathrm{m}^{2} \cdot \mathrm{K}$ \\
\hline$h_{c o-H S}$ & $\begin{array}{l}\text { Heat transfer Convection } \\
\text { coefficient of heat sink }\end{array}$ & ${ }_{2} \mathrm{~W} / \mathrm{K} \cdot \mathrm{m}$ & $\dot{H}_{\text {loss }}$ & The heat losses & $\mathrm{W}$ \\
\hline$\dot{\boldsymbol{H}}_{\text {fro }}$ & $\begin{array}{l}\text { Heat losses from front } \\
\text { surface of panel }\end{array}$ & $\mathrm{W}$ & $\dot{\boldsymbol{H}}_{\mathrm{re}}$ & $\begin{array}{l}\text { The heat losses at rear } \\
\text { surface of panel }\end{array}$ & $\mathrm{W}$ \\
\hline
\end{tabular}




\begin{tabular}{|c|c|c|c|c|c|}
\hline $\boldsymbol{Q}_{\square-s}$ & $\begin{array}{l}\text { Total heat dissipation from } \\
\text { heat sink }\end{array}$ & $\mathrm{W}$ & $q_{\text {acl }}$ & $\begin{array}{l}\text { The actual dissipated heat } \\
\text { from fin }\end{array}$ & W \\
\hline$q_{\max }$ & $\begin{array}{l}\text { The maximum dissipated } \\
\text { heat from fin }\end{array}$ & $\mathrm{W}$ & $\dot{\mathbf{I}}$ & Incident beam of solar ray & $\mathrm{W} / \mathrm{m}^{2}$ \\
\hline$\dot{\mathrm{I}}_{\mathrm{s}}$ & $\begin{array}{l}\text { Available solar energy for } \\
\text { solar panel }\end{array}$ & $\mathrm{W}$ & $\dot{\mathbf{I}}_{\text {reflected }}$ & $\begin{array}{l}\text { The reflected solar } \\
\text { radiation from glass covers } \\
\text { and solar cell layer }\end{array}$ & $\mathrm{W}$ \\
\hline$\dot{I}_{s 3}$ & $\begin{array}{l}\text { Solar panel absorbs energy } \\
\text { from solar irradiance at } \\
\text { cover glass layer }\end{array}$ & $\mathrm{W}$ & $\dot{\mathbf{I}}_{\mathrm{S} 1}$ & $\begin{array}{l}\text { Absorbed solar energy at } \\
\text { solar cells layer }\end{array}$ & $\mathrm{W}$ \\
\hline$\dot{\mathbf{I}}_{\mathrm{s} 2}$ & $\begin{array}{l}\text { Absorbed solar energy at } \\
\text { back insulation layer }\end{array}$ & $\mathrm{W}$ & $\dot{\mathrm{I}}_{\mathrm{s} 3-\mathrm{a}}$ & $\begin{array}{l}\text { The absorbed energy part } \\
\text { from incident beam at } \\
\text { cover glass }\end{array}$ & $\mathrm{W}$ \\
\hline$\dot{I}_{s 3-b}$ & $\begin{array}{l}\text { The absorbed energy by the } \\
\text { cover glass of a beam } \\
\text { reflects from cells layer }\end{array}$ & $\mathrm{W}$ & $\boldsymbol{k}_{\text {fin }}$ & $\begin{array}{l}\text { Thermal conductivity of } \\
\text { fin material }\end{array}$ & $\mathrm{W} / \mathrm{m} \cdot \mathrm{K}$ \\
\hline$K_{b-f}$ & $\begin{array}{l}\text { Heat sink base thermal } \\
\text { conductivity }\end{array}$ & $\begin{array}{l}\mathrm{W} / \mathrm{m} \cdot \\
\mathrm{K}\end{array}$ & $K_{\text {Ted }}$ & $\begin{array}{l}\text { Tedelar layer thermal } \\
\text { conductivity }\end{array}$ & $\mathrm{W} / \mathrm{m} \cdot \mathrm{K}$ \\
\hline$K_{\text {glass }}$ & Glass thermal conductivity & $\begin{array}{l}\mathrm{W} / \mathrm{m} \cdot \\
\mathrm{K}\end{array}$ & $K_{E V A}$ & EVA thermal conductivity & $\mathrm{W} / \mathrm{m} \cdot \mathrm{K}$ \\
\hline$K_{\text {cell }}$ & cell thermal conductivity & $\begin{array}{l}\mathrm{W} / \mathrm{m} \cdot \\
\mathrm{K}\end{array}$ & $\dot{m}$ & $\begin{array}{l}\text { Mass flow rate, equal to } \rho \\
\text { VA }_{\text {chs }}\end{array}$ & $\mathrm{kg} / \mathrm{s}$ \\
\hline$R_{t h}$ & The thermal resistance & $\mathrm{K} / \mathrm{W}$ & $R_{H S}$ & $\begin{array}{l}\text { heat sink thermal } \\
\text { resistance }\end{array}$ & $\mathrm{K} / \mathrm{W}$ \\
\hline $\boldsymbol{R}_{C}$ & $\begin{array}{l}\text { Convection thermal } \\
\text { resistance }\end{array}$ & $\mathrm{K} / \mathrm{W}$ & $\operatorname{Re}_{\mathrm{s}}$ & $\begin{array}{l}\text { Reynolds number depend } \\
\text { on fin spacing }=\mathrm{Vs} / v\end{array}$ & \\
\hline$R_{\text {equ }}$ & $\begin{array}{l}\text { Equivalent thermal } \\
\text { resistances of convection } \\
\text { and radiation at cover glass } \\
\text { of panel }\end{array}$ & $\mathrm{K} / \mathrm{W}$ & $R_{r-e q u}$ & $\begin{array}{l}\text { The equivalent resistance } \\
\text { of thermal radiation at the } \\
\text { front surface panel }\end{array}$ & $\mathrm{K} / \mathrm{W}$ \\
\hline Symbol & Meaning & Unit & Symbol & Meaning & Unit \\
\hline$\overline{R_{r f g}}$ & $\begin{array}{l}\text { The thermal radiation } \\
\text { resistances between glass } \\
\text { and ground }\end{array}$ & K/W & $P r_{\text {film }}$ & $\begin{array}{l}\text { Prantle number at film } \\
\text { temperature }\end{array}$ & \\
\hline$\overline{R_{r f s k y}}$ & $\begin{array}{l}\text { The thermal radiation } \\
\text { resistances between glass } \\
\text { and sky }\end{array}$ & K/W & $\sum R_{\text {Th-rear }}$ & $\begin{array}{l}\text { The sum of the resistances } \\
\text { of the upper half panel's } \\
\text { layers }\end{array}$ & K/W \\
\hline$\sum R_{\text {Th-top }}$ & $\begin{array}{l}\text { The sum of the resistances } \\
\text { of the upper half panel's } \\
\text { layers }\end{array}$ & $\mathrm{K} / \mathrm{W}$ & $S$ & $\begin{array}{l}\text { Channel width between } \\
\text { fins rows or columns = ds- } \\
D_{\mathrm{f}}\end{array}$ & $\mathrm{m}$ \\
\hline$T_{\mathrm{am}}$ & Ambient temperature & $\bar{K}$ & $T_{B}$ & Heat sink base temperature & K \\
\hline $\mathrm{T}_{\text {cell }}$ & Solar cell temperature & $\mathrm{K}$ & $\mathrm{T}_{\text {sky }}$ & The sky temperature & K \\
\hline $\mathrm{T}_{\mathrm{ref}}$ & $\begin{array}{l}\text { The reference temperature } \\
\left(25^{\circ} \mathrm{c}\right)\end{array}$ & ${ }^{\circ} \mathrm{C}$ & $\boldsymbol{t} \square_{b-f}$ & Heat sink base thickness & $\mathrm{m}$ \\
\hline $\boldsymbol{t} \square_{\text {cell }}$ & Cells layer thickness & $\mathrm{m}$ & $\boldsymbol{t} \square_{E V A}$ & EVR layer thickness & $\mathrm{m}$ \\
\hline$t \square$ glass & Glass cover layer thickness & $\mathrm{m}$ & $t h_{\text {Ted }}$ & Tedelar layer thickness & $\mathrm{m}$ \\
\hline$N_{f}$ & The total number of fins & & $U_{t}$ & $\begin{array}{l}\text { The overall thermal } \\
\text { resistance at front surface } \\
\text { of panel }\end{array}$ & $\mathrm{W} / \mathrm{K}$ \\
\hline
\end{tabular}




\begin{tabular}{|c|c|c|c|c|c|}
\hline $\mathrm{U}_{\text {rea }}$ & $\begin{array}{l}\text { The overall heat transfer } \\
\text { coefficient at rear side }\end{array}$ & $\mathrm{W} / \mathrm{K}$ & $\mathrm{V}$ & Voltage of the panel & $\mathrm{V}$ \\
\hline $\mathrm{V}$ & Wind speed & $\mathrm{m} / \mathrm{s}$ & $\Lambda_{\text {cell }}$ & The reflection coefficient & \\
\hline$\nearrow_{\mathrm{gl}}$ & $\begin{array}{l}\text { Transmissivity coefficient of } \\
\text { glass }\end{array}$ & & $\alpha_{\text {cell }}$ & $\begin{array}{l}\text { Absorptivity coefficient of } \\
\text { solar cell }\end{array}$ & \\
\hline$\eta_{\text {fin }}$ & Fin efficiency & & $\alpha_{\mathrm{b}-\mathrm{in}}$ & $\begin{array}{l}\text { Absorptivity coefficient of } \\
\text { back insulation layer }\end{array}$ & \\
\hline$\eta_{s c}$ & Cell efficiency & & $\eta_{r e f}$ & $\begin{array}{l}\text { Solar cell efficiency at } \\
\text { reference temperature }\end{array}$ & \\
\hline$\eta_{H S}$ & Heat sink efficiency & & $\in_{\text {glass }}$ & Glass cover emissivity & \\
\hline
\end{tabular}

\section{1-Introduction:}

Photovoltaic cells can be directly produced an electrical energy from an incident solar radiation upon it. The most functional, sustainable, and environmentally friendly systems are the PV modules. But the problem lies in its ability to convert part of the solar energy received into an electric energy and the significant part converts to heat which accumulate inside the solar module causing an increasing in temperature of the module [1]. Several parameters have an effect on PV system performance including temperature. The high temperature will lead to decrease module efficiency. This undesirable effect in conversion efficiency of PV module may be partly avoided by using a suitable method for extracting the unwanted heat [2]. Many researchers have proposed various procedures for achieving an enhancement in the performance of solar panels along with reducing in the installation costs. One of these methods is to use properties of extended surfaces in heat dissipation, [3]. Fins are the extensions of surfaces in an object to enhance the heat transfer rate by convection from or to the surroundings areas. Thus to achieve a high rate of heat transfer, the exchange surface area can be increased or enhanced the convection coefficient of heat transfer, or both at a time, [4]. But the natural convection in the heat sink can be achieved in good manner only with the optimization arrangement of its geometry, like fin dimensions and their spacing, [5]. Many researchers had been discussed in previous years that the fins arranged in the form of strip or an array of fins [5, 6, 7, and 8] (as a heat sink) caused an increasing in the surface area of heat transfer. In Some researches, the heat sinks were utilized to dissipate the excess thermal energy associated with the PV panel during the operating time and especially in hot climate areas to be as a passive cooling system. In ref $[5,7]$ the heat sink was fabricated as ribbed walls, made of materials with high thermal conductivity, while ref [9 and 10], presented studies in improving PV panel performance using passive fin cooling with natural ventilation. An optimized plate fin as a heat sink was used to cool a concentrating solar panel [11It can be concluded from the previous experimental and theoretical studies that the use of fins achieved an enhancement in PV panel performance within $2-10 \%$ in its output power according to the ways of used heat sink's geometries .

In the subject area, previous studies have found insufficient, which were published about densely cylindrical pin fin as heat sinks at the back of a solar panel to cool it naturally. It is therefore necessary to investigate this configuration to provide natural cooling. The use of Standalone configurations of solar 
module is the least methods to achieve enough cooling for it.

In present work, theoretical simulations and experimental results will be provided for improving the performance of solar module with the use of pin fins array (as a heat sink) for cooling in natural ventilation. Dimensions of the proposed pin fin heat sink have been optimized according to the steady-state and one dimensional heat transfer analysis results. Simulated and experiential performance results of the PV module with pin fins heat sink have been compared with the experiential performance results of the standalone PV panel.

\section{2- Mathematical Formulation:}

\section{Optimized of Heat Sink Dimensions:}

Cooling by a cylindrical pin fin as a heat sink might be a potential solution to overcome the problem of high temperature PV panel. Heat sink effect can provide a much greater potential convection heat transfer. It provides an increasing area of heat transfer. So It must be ensured that the overall effectiveness of heat sink is at least greater than 2, while its efficiency must be close to ideal conditions (of $\eta=1$ ). These considerations will ensure that the heat transmitted by the heat sink to the surrounding is maximized. Ideal conditions have been applied to be a comparative tool for the heat sink performance. Thermal analysis of heat sink has been built on an assumption that heat transfer is in one dimension and in steady state in determining thermal resistance (or thermal performance). Because it deals with one heat source (solar cells) and changes in environmental conditions are going smoothly throughout the day. Heat sink with cylindrical pin-fins will be used in the present analysis. It is characterized by high heat transfer coefficient due to weak recirculation flow which will contribute to providing a fresh air continuously, [12]. Pin fins array is also not affected by the direction of airflow such as a ribbed wall as a heat sink, [13]. Fins spacing are determined of $\mathrm{z} / \mathrm{d}=\mathrm{x} / \mathrm{d}=2.5$ for best performance, [14], see figure 1. In order to optimize heat sink dimensions, a thermal model is built to analyze its characteristics depending on all assumptions that has been mentioned above.

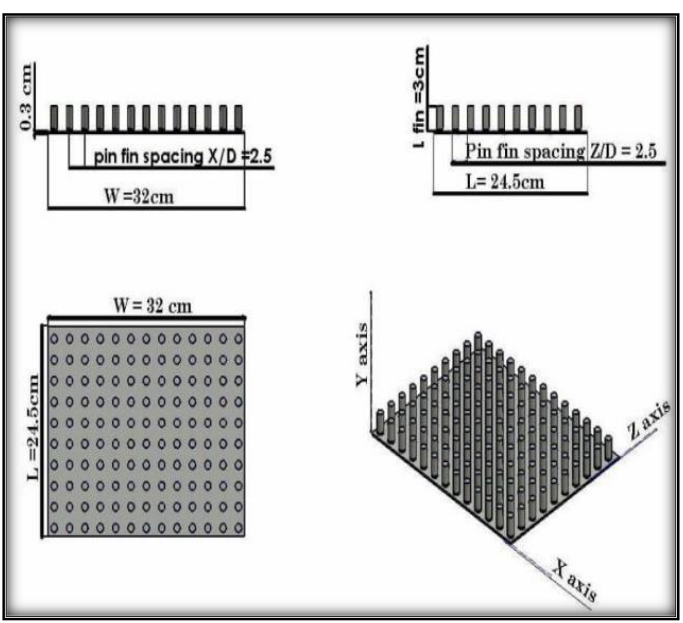

Total heat dissipation $\left(Q_{h-s}\right)$ from the heat sink is , [15]: $Q_{h-s}=$

$\left(h_{c o-H S}\right) \cdot\left(A_{f B}+\eta_{f i n} N_{f} A_{f i n}\right)\left(T_{B}-T_{a m}\right)$.

Where the thermal resistance is:

$R_{t h}=\frac{Q_{h-s}}{T_{B}-T_{a m}}=\frac{1}{\left(h_{c o-H S}\right) \cdot\left(A_{f B}+\eta_{\text {fin }} A_{\text {fin }}\right)}$

Fluid resistance is added to the heat sink thermal resistance to be as follows, [16]:

Figure1.Pin fins array as a heat sink geometry 
$R_{H S}=\frac{Q_{h-S}}{T_{B}-T_{a m}}=\frac{1}{\left(h_{c o-H S}\right) \cdot\left(A_{f B}+\eta_{f i n} A_{f i n}\right)}+\frac{1}{2 \dot{m} c_{p}}$

Thermal radiation resistance can be ignored according to Ref [17]. Equation 3 contains fin efficiency to cover the fin temperature different along the fin surface [15].

Fin efficiency can be determined by as following equation [18]:

$$
\eta_{\text {fin }}=\frac{q_{a c l}}{q_{\max }}
$$

Where q_max and q_acl for the case of an isolated tip of pin fin which has been considered in the current analysis, are to be as mention in Ref [18].

While $h_{c o-H S}$ of pin fins heat sink is, [14]:

$h_{c o-H S}=0.068 R e_{S}^{0.733} \operatorname{Pr}_{\text {film }}^{0.4} \times \frac{k_{\text {fin }}}{s}$

Properties of fluid (air) have been defined at film temperature.

The total number of fins in heat sink is calculated by

eq 6. $\quad N_{\text {fin }}=\frac{\mathrm{A}_{\mathrm{B}}}{d s^{2}}$

The base free area $\left(A_{f B}\right)$ can be defined as follows:

$$
A_{f B}=\mathrm{A}_{\mathrm{B}}-N_{f i n} \mathrm{~A}_{\mathrm{cf}}
$$

Heat sink thermal efficiency $\left(\eta_{H S}\right)$ of heat sink is calculated as following, [19]:

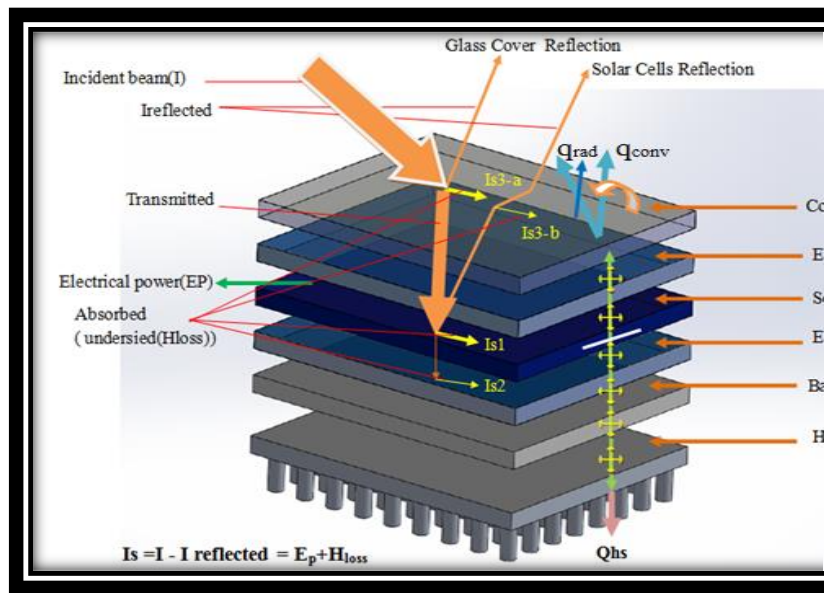

$\eta_{H S}=1-\frac{A_{\text {fin }}}{A_{\text {total }}}\left(1-\eta_{\text {fin }}\right)$

Where, $A_{\text {total }}=A_{f B}+A_{\text {fin }}$

Heat sink thermal effectiveness is defined as follow:

Effect esS $_{H}=\frac{Q_{h-S}}{h \mathrm{~A}_{\mathrm{B}} \triangle T}$

Where h, [20] is: $h=2.56 \mathrm{~V}+8.55$ ......11

\section{PV- COOL model Thermal analysis}

One configuration that leads to natural convection enhancement is the linking of extended surfaces (fins) on the back side of the solar module [4]. Heat sink and layers of PV panel used have been described in the physical system shown in figure 2 . The boundaries conditions for the studied case were included heat dissipation and output electrical power $\left(E_{p}\right)$ as output power and the received solar radiation (I) as input power to the module, see figure 3. heat dissipation encompasses the heat looses $\left(\dot{H}_{\text {loss }}\right)$ at the front of PV panel, by radiation ( $\left.\mathrm{q}_{\mathrm{rad}}\right)$ and convection ( $\mathrm{q}_{\text {conv }}$ ) heat transfer modes as well as the heat loss through a heat sink ( $\left.\mathrm{q}_{\text {heat sink }}\right)$ at rear of PV panel, as illustrated in figure 2.

Figure 2. Physical description of PV- COOL model 


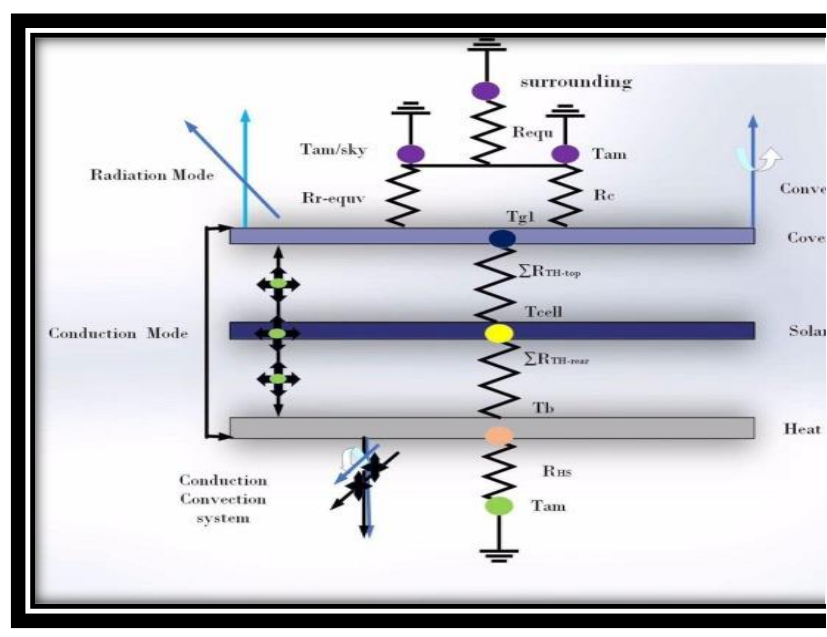

Figure 3. Thermal network simulation for PV cooling model

The construction of PVCOOL module is solar panel layers and heat sink as shown in Figure 2. And their dimensions and physical characteristic are as indicated in Table 1.

Table 1. Dimensions and physical characteristic of the suggested PVT module components

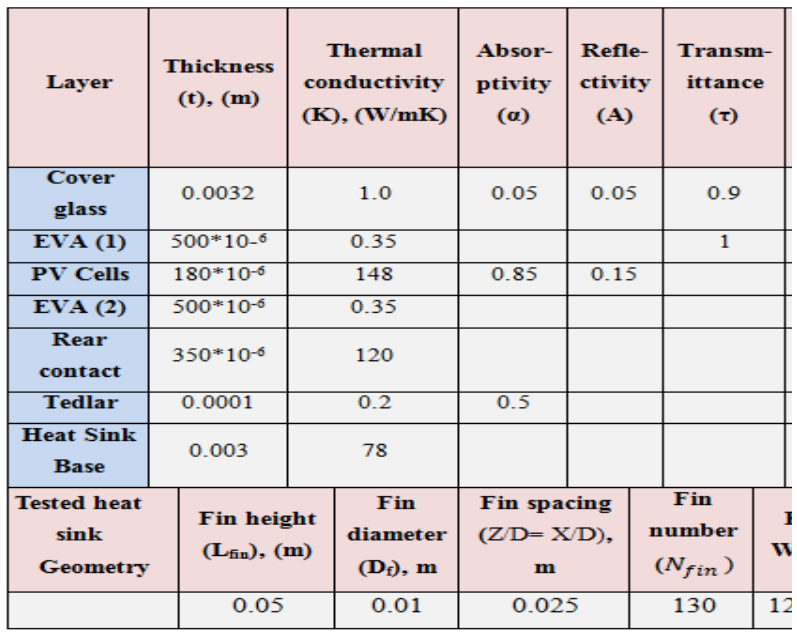

The solution of proposed thermal model is based on energy balance for one-dimensional analysis and steady state conditions along with data of climate conditions, dimensions and physical characteristic of module components. The associated climate conditions are; ambient temperature, solar radiation and wind velocity.

So the energy balance is: $\quad \dot{\mathrm{I}}_{\mathrm{s}}=\mathrm{E}_{\mathrm{p}}+\dot{H}_{\text {loss }}$

Where

$$
\dot{\mathrm{I}}_{\mathrm{s}}=\dot{\mathrm{I}} * \mathrm{Ap}-\dot{\mathrm{I}}_{\text {reflected }}
$$

$\dot{\mathrm{I}}_{\text {reflected }}$ : The reflected solar radiation from glass covers and solar cell layer, see figure 2 .

And

$$
\dot{I}_{s}=\dot{I}_{s 1}+\dot{I}_{2 s}+\dot{I}_{s 3}
$$

Where

$$
\left.\dot{I}_{\mathrm{s} 1}=\nearrow_{\mathrm{gl}} \dot{I} \text { Ap ( bc } \alpha_{\text {cell }}\right)
$$

$$
\dot{I}_{s 2}=\tau_{\mathrm{gl}} \dot{\mathrm{I}} \mathrm{Ap}(1-\mathrm{bc}) \alpha_{\mathrm{b}-\mathrm{in}}
$$

$$
\dot{I}_{s 3}=\dot{I}_{s 3-a}+\dot{I}_{s 3-b}=\alpha_{\mathrm{gl}} \dot{I} \mathrm{Ap}+\left(\widetilde{\mathrm{gl}}_{I} \dot{\mathrm{Ap} \mathrm{bc}}\right)
$$

$\Lambda_{\text {cell }} * \alpha_{\mathrm{gl}}$

$\dot{I}_{s 3}$ is the absorbed solar energy at cover glass layer $\left(\dot{I}_{s 3-a}\right)$ from the solar rays when penetrates the glass in its way to the solar cell and when it reflects $\left(\dot{\boldsymbol{I}}_{s 3-\boldsymbol{b}}\right)$ from solar cells, as shown in figure 2.

Therefore, the available solar power is as follows:

$\dot{I}_{s}=乙_{\mathrm{gl}} \dot{I} \mathrm{Ap}\left(\mathrm{bc} \alpha_{\text {cell }}\right)+乙_{\mathrm{g}} \dot{I} \mathrm{Ap}(1-\mathrm{bc}) \alpha_{\mathrm{b}-\text { in }}+\alpha_{\mathrm{gl}} \dot{I}$

$\mathrm{Ap}+\overline{\mathrm{gl}}_{\mathrm{gl}} \dot{I} \mathrm{Ap}\left(\mathrm{bc} \Lambda_{\text {cell }} * \alpha_{\mathrm{gl}}\right)$

where $\quad \Lambda_{\text {cell }}=1-\alpha_{\text {cell }}$

While the electrical energy $\left(\mathrm{E}_{\mathrm{p}}\right)$ is: $\eta_{s c=} \eta_{r e f}(1-$

$\left.0.0041\left(\mathrm{~T}_{\text {cell- }} \mathrm{T}_{\text {ref }}\right)\right)$

$\begin{array}{llllll}\mathrm{E}_{\mathrm{p}} & =\eta_{s c} & \boldsymbol{乙}_{\mathrm{gl}} & \text { Ap } & \text { bc } & \dot{I}\end{array}$ 
The heat losses ( $\dot{H}_{\text {loss }}$ ) is expressed as follows:

$\dot{H}_{\text {loss }}=\dot{H}_{\text {fro }}+\dot{H}_{\text {re }}$

Where $\quad \dot{H}_{\text {fro }}=\mathrm{U}_{\mathrm{t}}\left(\mathrm{T}_{\text {cell }}-\mathrm{T}_{\mathrm{am}}\right)$

And

$$
U_{t}=\left(\sum R_{\text {Th-top }}+R_{\text {equ }}\right)^{-1}
$$

$\ldots$ (23) $\sum R_{\text {Th-top }}=\left(\frac{t h_{\text {cell } / 2}}{A_{P} K_{\text {cell }}}+\frac{t h_{\text {EVA }}}{A_{P} K_{E V A}}+\frac{t h_{\text {glass }}}{A_{P} K_{\text {glass }}}\right)$

$\ldots(24) R_{e q u}=\left[\frac{R_{r-e q v}+R_{C}}{R_{r-e q u *}}\right]^{-1}$

Convection resistance $\left(R_{C}\right)$ [21] is:- $R_{C}=\frac{1}{A_{p} h_{p}}=$ $\frac{1}{A_{p}(2.56 V+8.55)}$

Thermal resistances of heat transfer by radiation between glass with the ground and the sky are [21 \&22]:

$$
R_{r f s k y}=\frac{1}{4 F_{s k y} \in_{g l a s s} \sigma A p T_{s k y}^{3}}
$$

and $\quad R_{r f g}=\frac{1}{4 F_{g} \in_{g l a s s} \sigma A p T_{a m}^{3}}$

Where [23], $\quad \mathrm{F}_{\mathrm{sky}}=1-\frac{1}{2}(1+\cos (180-\varphi))$

and $F_{g}=\left(1-F_{f}-\right.$ sky $)$

$$
\text { So } R_{r-e q v}=\left[1 / R_{r f s k y}+1 / R_{r f g}\right]^{-1}
$$

Sky temperature $\left(\mathrm{T}_{\text {sky }}\right)$ can be calculated by [24]:

$\mathrm{T}_{\mathrm{sky}}=0.0552 \times\left(T_{\text {am }}\right)^{1.5}$

The heat loss at rear surface of panel $\left(\dot{H}_{\text {re }}\right)$ is: $\dot{H}_{\text {re }}=$

$\mathrm{U}_{\text {rea }}\left(\mathrm{T}_{\text {cell }}-\mathrm{T}_{\mathrm{am}}\right)$

$$
\mathrm{U}_{\text {rea }}=\quad\left(\sum R_{\text {Th-rea }}+R_{H S}\right)^{-1}
$$

$$
\begin{aligned}
& \sum R_{T h-r e a}=\left(\frac{t h_{c e l l} / 2}{A_{P} K_{c e l l}}+\frac{t h_{E V A}}{A_{P} K_{E V A}}+\frac{t h_{T e d}}{A p \cdot K_{T e d}}+\right. \\
& \left.\frac{t h_{b-f}}{A p \cdot K_{b-f}}\right)
\end{aligned}
$$

The resistance of heat $\operatorname{sink}\left(R_{H S}\right)$ is calculated by equation 3 .

At substituting all terms in equation 12 by equivalent, and rearranging it, $\mathrm{T}_{\text {cell }}$ can be calculated by equation 37.

$$
T_{\text {cell }}=\frac{\dot{I}_{s}-0.165 \tau \mathrm{g} b c \mathrm{Ap} \dot{I}+\mathrm{T}_{\mathrm{am}} \mathrm{Utop}+\mathrm{T}_{\mathrm{am}} U_{\text {rea }}}{-0.000615+\mathrm{Utop}+U_{\text {rea }}}
$$

\section{Experimental Setup:}

Figure (4Aand 4B) presents the experimental setup. it consists of two $10 \mathrm{~W}$ monocrystalline panel, with an effective area (Ap) of $0.09975 \mathrm{~m}^{2}$ and maximum product of the voltage and current $22 \mathrm{~V}$ and $0.59 \mathrm{~A}$ respectively in standard conditions ( $1000 \mathrm{~W} / \mathrm{m}^{2}$ irradiance at $25^{\circ} \mathrm{C}$ ). A passive cooling manner for solar panel is used by heat sink consisted of aluminum alloy fins (cylindrical pin fins) with thermal conductivity of $123.84 \mathrm{~W} / \mathrm{m} . \mathrm{K}$ and it was manually manufactured. Heat sink dimensions have been specified according to the one dimension and steady-state analysis results of heat transfer to be $2.5 \mathrm{~cm}, 1 \mathrm{~cm}, 5 \mathrm{~cm}$ for fin spacing, fin diameter and fin length respectively. The validation of this heat sink arrangement has been inspected by intensive discussion which will be posterior presented. The heat sink consisted from 130 cylindrical fins; its dimensions are explained in figures 1. The heat sink has been fabricated from an aluminum alloy sheet and 130 rods of $1 \mathrm{~cm}$ diameter and $5 \mathrm{~cm}$ length see Figure 1. Heat sink was formed by digging130 penetrative holes in the sheet (base of heat sink) to place the fins. The distribution of fins was based on simulation results. The rods were inserted as fins into the holes tightly to be in touch with the surface of the hole and the rear panel surface. And then, the back side of the heat sink has been polished very well as shown in Figure 4. 

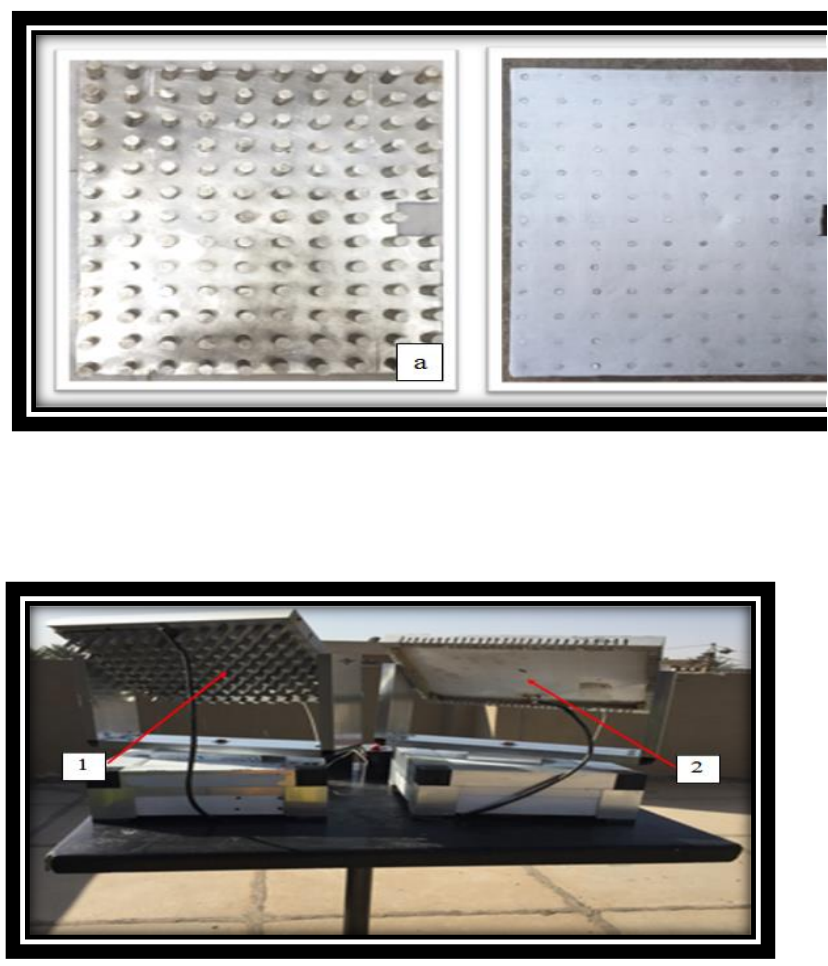

[1-PV panels Rear sides with cooling system , 2-PV panels Rear sides without cooling system]

Figure 5. (a) PV panels Rear sides with and without cooling system

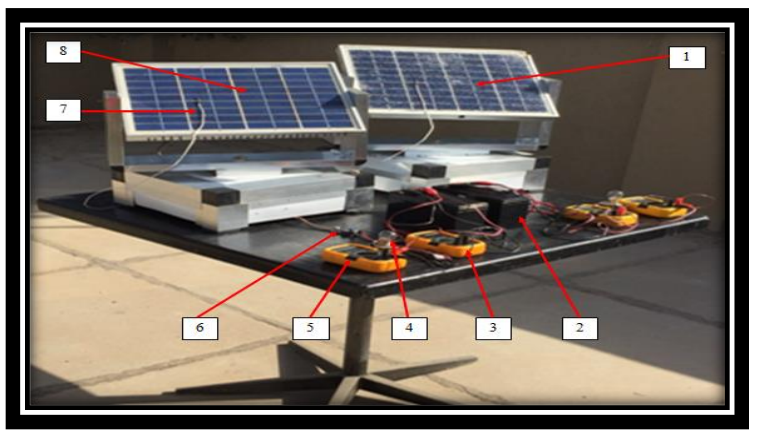

[1-PV panels cooling system , 2- Battery type ( SLA $12 \mathrm{~V} * 9 \mathrm{AH}$ ) ,3- Digital multi meter (as Volt meter), 4- Load, 5- Digital multi-meter (as Ammeter) , 6-
Figure 4. Manufactured heat sink (a) Front side (b)

Back side

The heat sink was linked on the panel's rear side using thermal gel. A standalone PV panel was used to compare its performance with the panel which was integrated with the heat sink. The panels have been fitted with a 32.1 deg tilt angle and facing the south [24], see figure 5 .

Voltage regulator , 7- thermocouple , 8- PV panels Rear sides without cooling system]

\section{Figure 5. (b) Experimental setup}

The current work has been done in Baghdad city, located at $33^{\circ} 19^{\prime}$ North, $44^{\circ} 25^{\prime}$ East, [18]) . The experiments were conducted in July 2017 from 9:00 am to 4:00 pm. Panel's temperatures were measured by a temperature recorder (LUTRON BTM-4208SD type) with accuracy about $\pm 0.3{ }^{\circ} \mathrm{C}$. Thermocouples were placed at front and rear sides for two panels (with and without heat sink), to measure their temperatures. Solar irradiance has been measured by solar meter (pyranometer, SPM 1116SD type). The output current and voltage have been recorded using a digital multimeter( type Fluke 179). The instant wind velocity at $2 \mathrm{~m}$ above the panel location was measured. Data recording was repeated in a 20 minute interval for two panels (without and with cooling) concurrently. In order to confirm the results, the test was repeated several times on different dates. The measurement devices have been calibrated previously.

\section{Results and Discussion:}

Thermal performance of PV module with cooling system was formulated theoretically. The used PVCOOL system has been created from cylindrical pin fins arranged in-line array as a heat sink. The 
thermal performance and dimensions of pin fin and

heat sink that created from them, was depicted

through a mathematical model built for this purpose.

The proposed method was then validated

experimentally.

\section{Best Finned Heat Sink Geometry:}

The purpose of the search in the optimal heat sink geometry is to be in perfect form to use as a solution for overheating in the solar panel. Reference [14] indicated that the best space between pin fins to be 2.5 D. Therefore, the fins number in heat sink base area is determined depending on this result for spacing and the fin's diameter. Figure 6 shows that the relation between fin's diameter and fin's number is linear. The effects of fin's diameter along with the fin's length have been investigated mathematically, on the heat sink efficiency and effectiveness as well the amount of heat dissipation, as shown in figures $(7,8 \& 9)$ respectively.

In these figures, fin's diameter was varied between 0.4 $\mathrm{cm}$ to $1.9 \mathrm{~cm}$ with $0.3 \mathrm{~cm}$ increment and fin's length from 3 to $7 \mathrm{~cm}$ with $1 \mathrm{~cm}$ increment. Figure 9 shows that the increasing of fin's diameter leads to enhance the efficiency of heat sink, while the effectiveness as well heat dissipation are gradually decreased, see Figure 7 and 8. Also these figures present the effects of fin's length on thermal performance of heat sink.

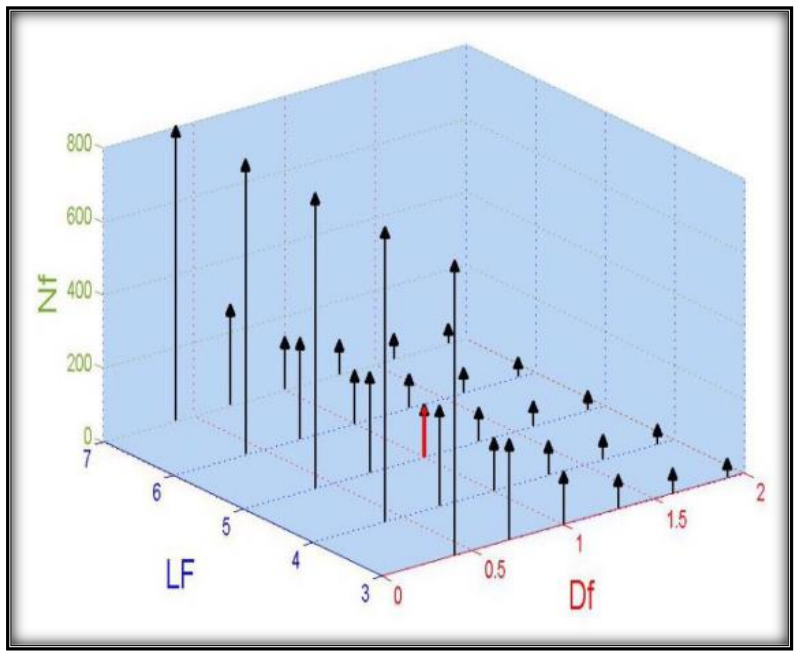

Usually, the increase of the fin length leads to improve heat dissipation and effectiveness of heat sink due to the increase of heat exchange area, see Figures 8and 9, while the increasing of fin length leads to a slight decrease of heat sink efficiency due to increase in thermal resistance as shown in Figure 10. Within the scope of the current adopted fin length, it can be concluded that there are a very little effect in thermal parameters of heat sink, as shown in the above Figures as well as Figure 10. Figure 10 illustrates the change of heat sink's overall thermal resistances with the different lengths and diameters of the fin. This figure indicates that the fin having a greater diameter gave a high thermal resistance with a little effect of increasing in fin's length. Fins with high length are useful for increasing the heat dissipation area but, it will be caused in increasing the heat sink mass. Therefore, an appropriate length should be selected in the practical design. This figure indicates that fin having the greater diameter gave a high thermal resistance with a little effect of increasing fin's length. Fins having high length are useful for increasing the heat dissipation area but, it will be caused in increasing the heat sink mass.

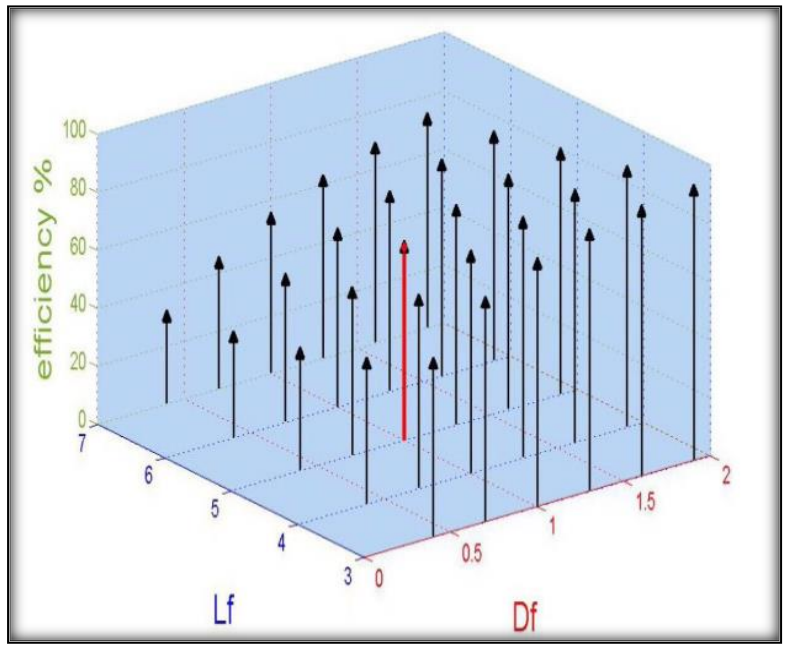


Figure 6. The number of fins vs.

fin diameters and lengths

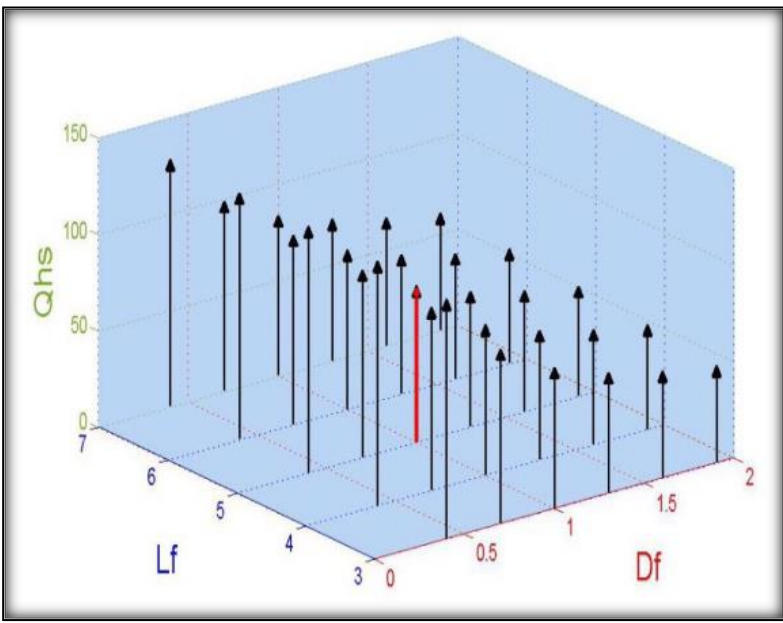

Figure 8. Heat sink effectiveness vs. different fin's lengths and diameters
Figure7. Heat sink efficiency vs.

diameters and lengths of fin

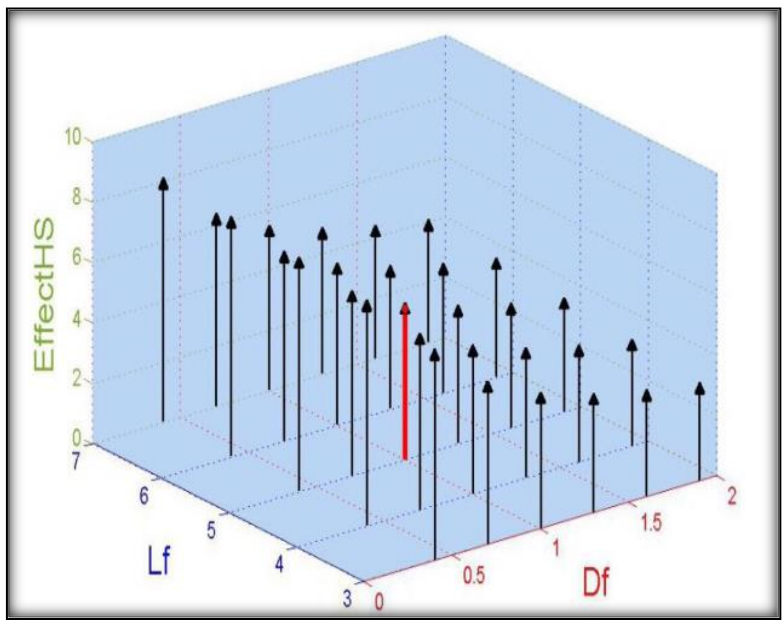

Figure 9. Heat dissipation vs.

different fin's lengths and diameters

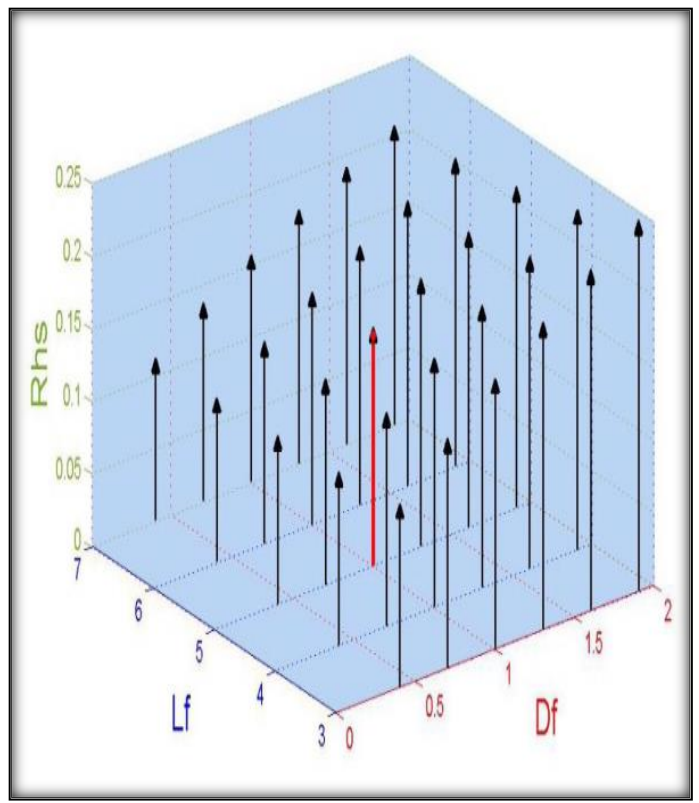

Figure 11 shows the calculated and measured temperatures of PV module with using the suggested heat sink as a cooling system. Experimental results have been got when heat sink was fabricated depending on analytical results and used as a cooling
And fins with small diameter will be hardly manufactured due to increase in fins number for the specific area of heat sink base and it may also be easily broken during the manufacturing process. According to the following considerations; lower cost and easily fabrication, fins length and diameter and base thickness of heat sink have been chosen to be $50 \mathrm{~mm}, 10 \mathrm{~mm}$, and $3 \mathrm{~mm}$ respectively. The selected fin dimensions were marked in above Figures in red color. This heat sink will be utilized as a PV cooling method in current work.

Figure 10. Overall thermal resistances Vs. fin length and diameter

\section{II.Theoretical and Experimental Investigation for the PVCOOL system performance:}

method, in order to validate the performance of the thermal model. The comparison between calculated and measured temperatures shows good accuracy with variance not more than $1.2^{\circ} \mathrm{C}$. This Figure shows that the temperature distribution profiles of 
solar panel were almost having the same tendency for different cases (without and with cooling).This detects the reliable performance of the solar panel with different operation conditions. Also, it can be observed that the highest module temperature occurred at a period between 1:00 and 2:00 PM which will be called the peak time.

For the PV panel temperature without cooling, as shown in Figure 11 a highest temperature has been recorded during the time of experimentation with a maximum temperature of $69.5^{\circ} \mathrm{C}$ at peak time. The module temperature was reduced about $61.5^{\circ} \mathrm{C}$ in the same period at cooling with heat sink. This was corresponded to the reduction in module temperature about $11.5 \%$ and $9.98 \%$ for the daily average temperature

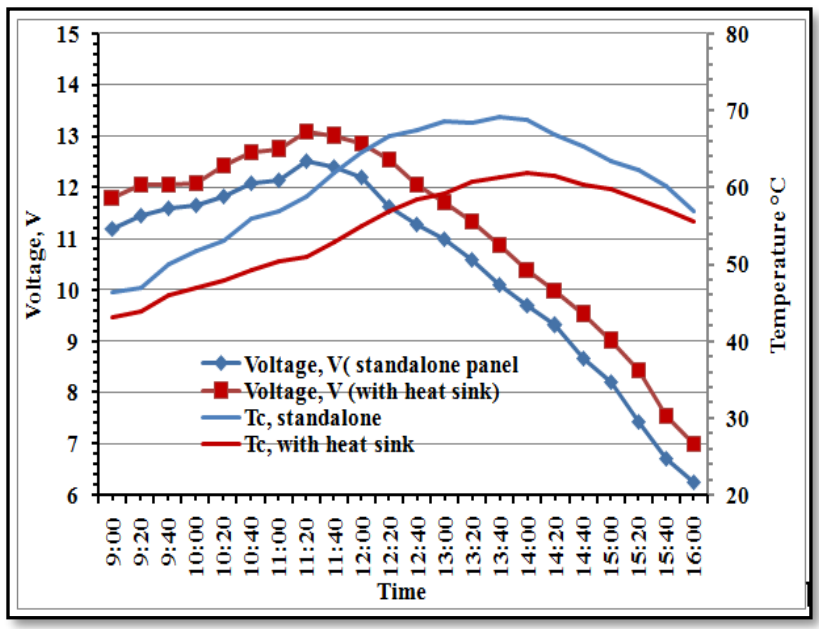

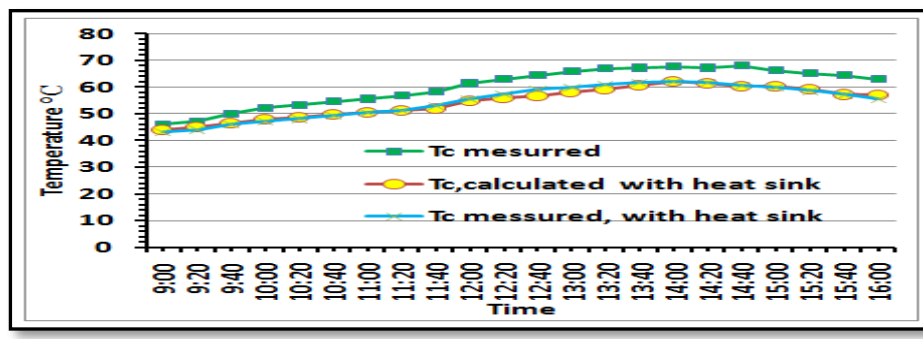

Figure11. Temperatures profile of calculated and measured solar module

which may be attributed to increase in the surface area of heat exchange at the rear face of panel. The variation of output voltage, current, power and efficiency of solar panels with the time at different operation conditions are presented in Figures 12, 13, 14 and 15. It may be inferred that the electrical characteristics output are improved when the solar panel is supplied with cooling arrangement.

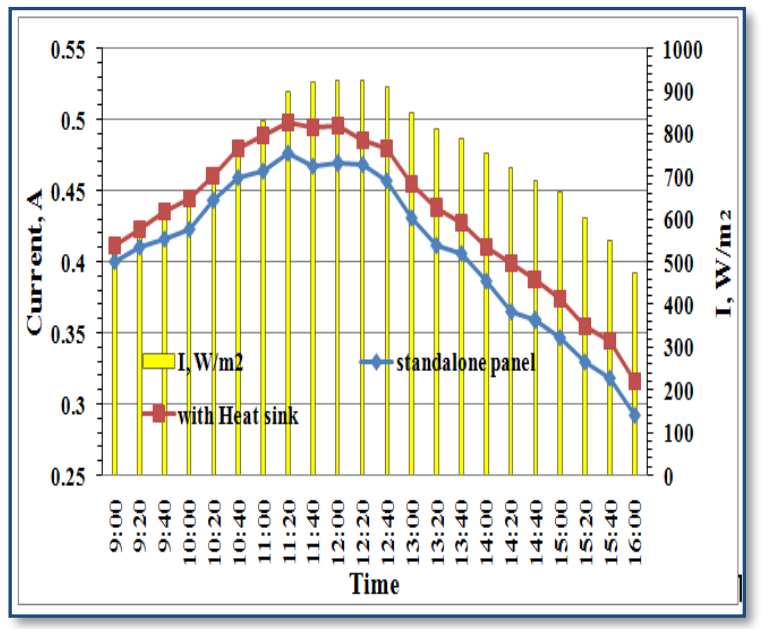

Figure 12. Output currents of PV module along with incident radi

ation.

along with panel

temperatures

The electrical characteristics of the photovoltaic module can be summarized in the relationship between both of the output voltage and current. Figures 12 and 13 show the effects of the proposed cooling system on
Figure13. Output voltages of PV module

both output voltage and current of the modules with time. The use of heat sink as a cooling systems achieved an improvement in daily average of output currents about $5.55 \%$, and outputted voltages about $6.63 \%$, compared with the standalone panel voltage 
output. The improvements are occurred due to the reduction in $\mathrm{PV}$ temperature

The amount of solar irradiance determines the amount of output current and the operating temperature of solar panel affects in the output voltage (V). Figure 14 presents the variation of the output power with time for module with heat sink as a cooling system along with radiation data. Figure 14 shows that the output power for the panel without cooling arrangement (standalone) is the least at a value about 4.37W, while the output power for the PV panel with

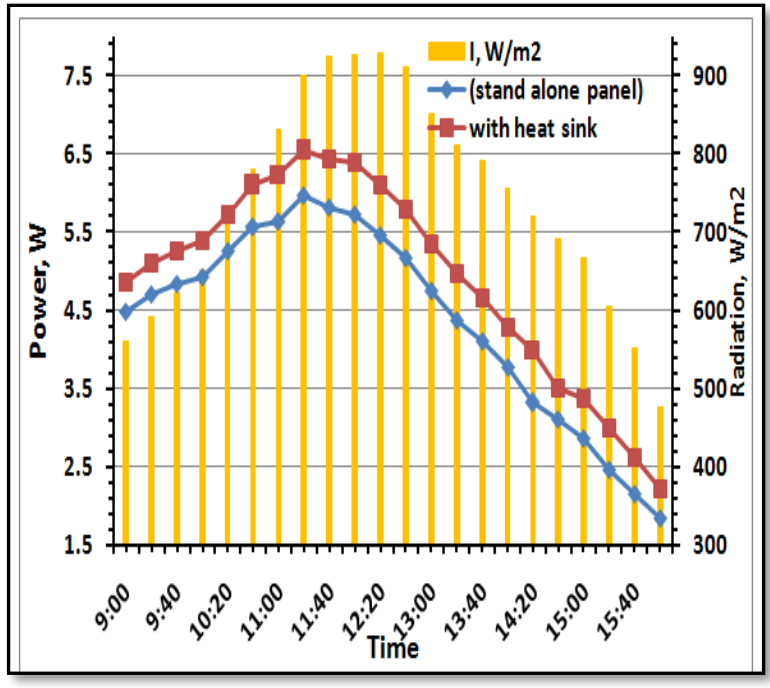

heat sink is $4.96 \mathrm{~W}$. The daily average enhancement is about $13.5 \%$, for using heat sink arrangement. The variation of solar module efficiency with the time is presented in figure (15) along with the module operation temperatures of the panel with and without cooling. The average efficiency along time operation is the smaller at a value $6 \%$ without cooling. The average panel efficiency has been enhanced about 11.6 $\%$ to be about $6.7 \%$ at using the heat sink. The experimental results point out that the solar panel temperature has a significant

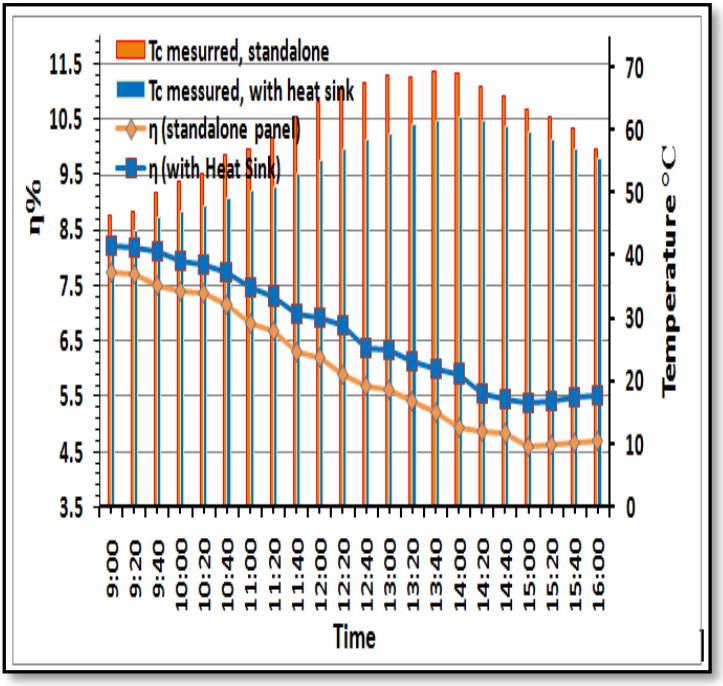

Figure 14. output power along with the solar radiation

and output power of PV module or, the rising of PV module temperature leads for decreasing the output power followed by a reduction in electrical efficiency of PV module as shown in Figure 15.

\section{5- conclusion:}

A passive cooling system,( a pin fin as a heat sink) is fixated to a flat PV panel to reduce the module's operating temperature in order to enhance the solar module performance. The following remark conclusions can be derived:
Figure 15. panel efficiency along with

the solar module temperature influence on the efficiency

1- The solar panel maximum temperature about $70{ }^{\circ} \mathrm{C}$ and an average temperature about $62^{\circ} \mathrm{C}$, without cooling.

2- The maximum module temperature is $63{ }^{\circ} \mathrm{C}$ and about $55.7^{\circ} \mathrm{C}$ for the average value when the heat sink is used as a cooling method.

This corresponds with the reduction in temperature of module about $9.1 \%$.

3- The proposed thermal model gives good accuracy for predicting module temperatures ( panel with finned surface as a heat sink) with variance not exceed than 1.2 ${ }^{\circ} \mathrm{C}$. For the measured temperatures under 
same operation conditions. that is indicated to use The thermal model as a tool to examine other geometry of heat sink

4- Cooling the module by pin fins (as a heat sink) affects the voltage and current production which leads ultimately to increase an average output power about $13.5 \%$, comparatively to the average output power of standalone panel, and an enhancement about $12 \%$ for the average efficiency.

5- Heat sink geometry and dimensions must be optimized in order to determine the best performance with a low cost and easily fabrication at using it as a solution for overheating problem in solar panel.

\section{References}

[1] Gotmare, ,A. J., Borkar, ,S.D., Hatwar, ,R.P., 2015,"Experimental Investigation Of Pv Panel With Fin Cooling Under Natural Convection", International Journal of Advanced Technology in Engineering and Science.

[2] Hosseini, ,R., Hosseini , ,N., Khorasanizadeh, , H.,2011, "An experimental study of combining a photovoltaic system with a heating system”, World Renewable Energy Congress Sweden .

[3] Kraus, ,A. D., Aziz, ,A., and Welty, , J., 2002,"Convection with simplified restraints "Extended Surface Heat Transfer, John Wiley \& Sons., New York.

[4] Piyush, , K. K., priyanka, , J., 2016,"Enhancement of Heat Exchanger Performance by the Extended Surfaces-Fins", International Journal of Engineering Trends and Technology (IJETT).

[5] Kraus, ,A. D., Aziz, ,A., and Welty, , J. , 2002, “Heat Transfer considerations " Extended
Surface Heat Transfer, John Wiley \& Sons, New York.

[5] Cătălin , ,G.P., Sebastian, ,V. H., Theodor , ,D.M., Nelu , ,C.C.2016, “Efficiency improvement of photovoltaic panels by using air cooled heat sinks" ,Energy Procedia 85425 - 432 .

[6] Hetsroni a , ,G., Mosyak, , A., Segal, , Z., Ziskind , ,G., 2002,“'A uniform temperature heat sink for cooling of electronic devices", International Journal of Heat and Mass Transfer, 3275-3286

[7] Erdem , ,C. , Tulin, ,B. and Suphi , ,A.S. ,2011, ““ Effects of passive cooling on performance of silicon photovoltaic cells", international Journal of LowCarbon Technologies.

[8] Cuce, , E., Bali, , T., and Sekucoglu, ,S. A.,2011, "Effects of passive cooling on performance of silicon photovoltaic cells", International Journal of Low-

Carbon Technologies, 299-308.

[9] Gotmare1, ,A.J., Borkar2, ,S.D., P.R. Hatwar, 2015“Experimental Investigation Of PV Panel With Fin Cooling Under Natural Convection”, International Journal of Advanced Technology in Engineering and Science Volume.

[10] Hongbing, ,C., Xilin, ,C., Sizhuo, , L., Hanwan, , D. ,2014, "Comparative study on the performance improvement of photovoltaic panel with passive cooling under natural ventilation", International Journal of Smart Grid and Clean Energy. [11] Luque, ,A., Sala, ,G., Arboiro, ,J., Bruton, ,T., Cunningham, ,D., and Mason, ,N., 1997, "Some results of the EUCLIDES photovoltaic concentrator prototype" Progress in Photovoltaics Research and Applications.

[12] Nabati, , H.,2008, “Optimal Pin Fin Heat

Exchanger Surface”, Msc Thesis, No 88 School of Sustainable Development of Society and Technology. Malardalen University, Sweden. 
[13] Shaukatullah , ,H., Storr , ,W. R., Hansen, ,J.B., Gaynes , ,A.M., 1996,“Design and optimization of pin fin heat sinks for low velocity applications", 12th IEEE SEMI-THERM Symposium, pp.151-163.

[14] Chyu, ,M. K., 1990,"Heat Transfer and Pressure Drop for Short Pin-Fin Arrays With Pin-Endwall," ASME Journal of Heat Transfer, Vol. 112, pp. 926932.

[15] Corominas, , J. G.,2011, "Heat Sink Analytical Modeling" Master thesis, Department of Electrical Engineering and Energy Systems Higher School of Electricity, SUPELEC, France.

[16] Robert, , J. M.,2008, “Modeling Air-Cooled Heat Sinks as Heat Exchangers", Design, Heat Pipes, Number 1, Test \& Measurement Heat Exchanger, Heat Pump, Model, February 1,. https://www.electronics-

cooling.com/2008/02/modeling-air-cooled-heat-sinksas-heat-exchangers,

[17] Royne, , A., Dey, ,C. J., and Mills, ,D.

R.,2005,“'Cooling of photovoltaic cells under concentrated illumination: a critical review" Solar Energy Material \& Solar Cells, 86, 451-483.

[18] Xu, , J.L., Gan, ,Y. H. , Zhang, ,D.C., Li, , X. H.,2005, "Micro scale heat transfer enhancement using thermal boundary layerre developing concept." Int J H. M. Transf;48(9):1662-74.

[19] Armstrong , ,S., Hurley , ,G.W.,2010, “A thermal model for photovoltaic panels under varying atmospheric conditions" Applied Thermal Engineering 30, 1488e1495.

[20] Wong, ,L.T. and Chow, ,W.K,2001, "Solar radiation model.” Applied Energy 69 pp 191-224. [21] Test, , F. L., Lessmann, ,R. C. and Johary, ,A.1981, "Heat transfer during wind flow over rectangular bodies in the natural environment".

Transactions of the ASME J. H. T. 103, 262-267 .
[22] Lu, , Z.H., Yao , ,Q., 2007,“Energy analysis of silicon solar cell modules based on an optical model for arbitrary layers", Solar Energy 81, 636-647. [23] Wong, , L.T, and Chow, ,W.K ,2001, "Heat transfer during wind flow over rectangular bodies in the natural environment" Transactions of the ASME J. Heat Transfer 103, 262-267.

[24] Jakhrani, ,Q.A.,Othman, ,K. A., Rigit, ,H.R.and Samo , ,R.S.,2011, “Comparison of Solar Photovoltaic Module Temperature Models" World Appl. Sci. J., 14 (Special Issue of Food and Environment).

[25] Can, ,C., Ugurtan, ,T., Ozgur, ,S., Zuhal, ,O., 2017, "Sensitivity analysis of implicit correlations for photovoltaic module temperature: A Review", Journal of Cleaner Production, Volume 164, 15 October 2017, Pages 1474-1485. 